\title{
Verification on Delay Time Adequacy of RSG GAS (Reaktor Serba Guna - G.A. Siwabessy) Control Elements
}

\author{
Azizul Khakim ${ }^{1}$ \\ 1. Badan Pengawas Tenaga Nuklir (BAPETEN) \\ J1. Gadjah Mada 8 Jakarta, Indonesia \\ e-mail: a.khakim@bapeten.go.id
}

\begin{abstract}
The capability of control elements to manage the reactor operation does not merely relay on their negative reactivity worth, but also the speed required to shutdown the reactor when operation state leads to an accident condition. The response speed of control elements is characterized by delay time which comprises of instrumentation response and dropping time. The adequacy verification on delay time was performed against fast reactivity transient due to inadvertant control rod withdrawal by observing safety parameters at peak power. Three delay times were analized using PARET/ANL code for fast reactivity transients. The calculation results confirmed that the delay time may not exceed $0.5 \mathrm{~s}$.
\end{abstract}

Keywords- delay time; control element; dropping time; instrumentation response.

\section{INTRODUCTION}

Control element is a reactivity control device which is important to the reactor safety as regulated by Indonesian national regulation of BAPETEN chairman regulation No.1/2011 [1]. Control elements function as neutron absorber, power control of reactor operation, as well as terminating reactor operation both during normal condition and conditions leading to accidents. Control elements should be evaluated based on both negative reactivity they provide and the insertion speed into the core when scram is required.

The speed of terminating the reactor operation is very much influenced by the response time of control element instrumentation system and rod dropping time. Response time of the control instrumentation system is the time needed from the activated trip signal through the time of rod actuation to drop.

How fast the reactor operation can be stopped very much depends upon the response time of the control instrumentation system and dropping time of the rods. The response time of control instrumentation is defined as the time required from activated trip signal through actuated system to drop the control rods. On the other hand, dropping time is defined as the elapsed time from the release of rods holder through the lowest position of the control rods. Both constitute to the total delay time. Dropping time of the control rods is normally more dominant contributor to the total delay time than the instrument response time. The dropping time must be less than certain value in such to prevent the occurence of excessive power deviation, particularly during fast reactivity insertion accident leading to abrupt power increase.

On the other hand, the requirement to meet minimum shutdown margin is intended to ensure that the reactor can be shut down in any conditions including the most reactive core condition, where the control rod having the highest reactivity fails to insert into the core typically known as one struck rod criteria. The most reactive condition of equilibrium core refers to Beginning of Cycle (BOC), cold, and clean without xenon. In this condition, the core excess reactivity is maximum.

In this paper, the analysis is aimed at verifying the adequacy of delay time inherently attached to the control rods, especially during fast power excursion due to positive reactivity insertion which requires scram action very soon. Calculation on three delay times were performed during reactivity accidents to observe the important safety parameters such as fuel and clad temperatures, and flow stability parameter.

\section{DESCRIPTION ON CORE AND CONTROL ELEMENT}

The equilibrium core of RSG GAS consist of 40 standard fuel elements and 8 control elements. The reactor core composed of 10x10 grids which is surrounded by berylium reflector [2]. Two sides of the core are surrounded by berylium block reflectors consisting of three layers. The other two sides are filled with berylium elements inserted into the grids.

The reactor is controlled by 8 control elements which are comprised of 15 fuel plates and 2 fork-type blades of absorber material [3]. The fuel plates in the control element is exactly the same as of those in the fuel element. The absorber material is made of AgInCd. The absorber is claded by SUS-316L. The control element of the reactor are located at positions B-7, C-5, C-8, D-4, E-9, F-5, F-8, and G-6 [3,4]. In addition, the absorber material AgInCd is also widely used in power reactor of PWR (Pressurized Water Reactor). 
Figure 1 shows the description of the control element. The absorber material AgInCd has 3.38 $\mathrm{mm}$ thick and $63.7 \mathrm{~mm}$ wide, and $0.58 \mathrm{~mm}$ of clad thickness.

\section{CALCULATION MODEL}

The equilibrium core of RSG GAS with nominal power of $30 \mathrm{MW}$ is assumed to be divided by two cooling channels, i.e, one channel as hot channel representing the most severe condition of the fuel, and the rest of the core as average channel representing the average behavior of the fuels during transient.

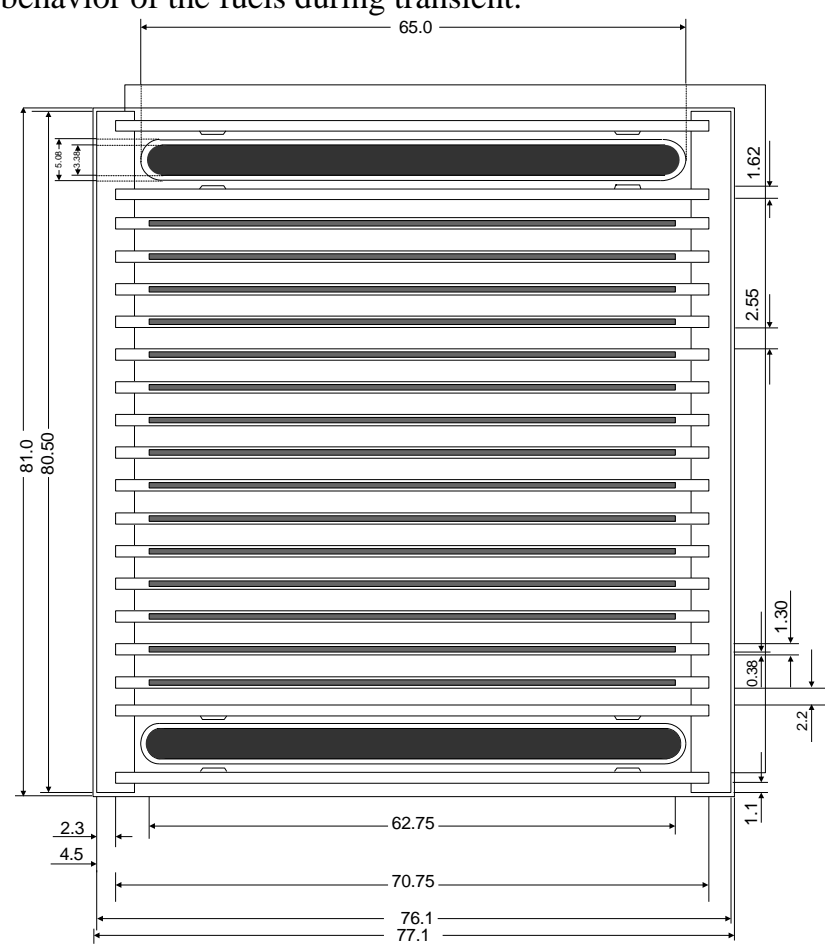

Figure 1. Control element of RSG GAS

Transient of positive reactivity insertion leads to rapid power reactor increase which requires protection response from the control rods to shut down the reactor quickly. Among the potential sources of positive reactivity insertion, the biggest positive reactivity is of inadvertant control rods withdrawal. Transients of inadvertant control rods withdrawal could take place during:

1. Natural cooling mode with power of less than $300 \mathrm{~kW}$ [5],

2. Forced convection cooling mode with initial power of $1 \mathrm{MW}$ [6], and

3. Forced convection cooling mode at nominal power of $30 \mathrm{MW}$ [7].

Among the aforementioned reactivity transient, reactivity insertion with initial power of $1 \mathrm{MW}$ at forced convection cooling mode results in fast and high reactor power increase. Herewith, to analyze control rod delay time adequacy, the scenario No. 2 is the most limiting condition and is selected for verification.

Therefore, analysis is done for initial power of $1 \mathrm{MW}$. The accident is assumed to be initiated by inadvertant all control rods leading to positive reactivity insertion into the core. In the accident scenario, single failure criteria is applied, where the first trip signal coming from floating limit value is assumed to fail to scram the reactor. The second trip signal from over power signal eventually scram the reactor. The over power trip signal is $114 \%$ of its nominal power (34.2 MW). Three calculations have been done for delay time of $0.5 \mathrm{~s}, 1.0 \mathrm{~s}$ and $1.5 \mathrm{~s}$. The reactor is undergoing normal cooling, i.e. downward forced convection. The transient starts at time $\mathrm{t}=5 \mathrm{~s}$.

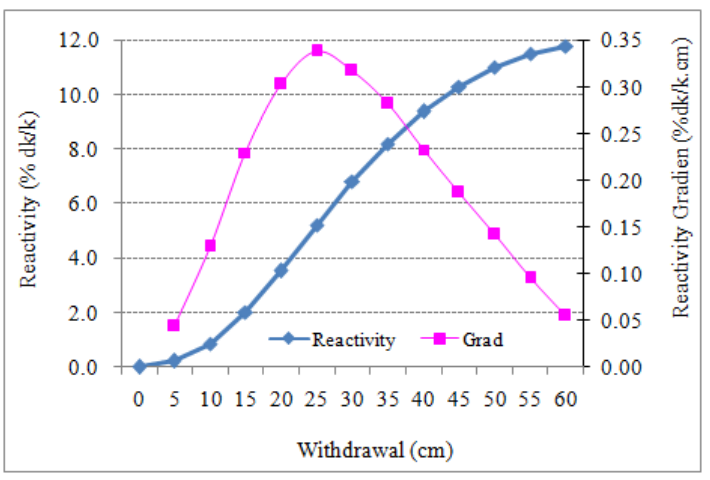

Figure 2. The $\mathrm{S}$ curve and reactivity gradient of control rods calculated by MCNP5

The reactivity insertion rate is taken at the maximum value calculated from $\mathrm{S}$ curve with MCNP5 code [8], as shown in Figure 2. The code has been validated against first criticality of RSG GAS [9]. The figure implies that its maximum reactivity gradient stand at $0.338 \% \mathrm{dk} / \mathrm{k} . \mathrm{cm}$. Considering the maximum speed of $0.0564 \mathrm{~cm} / \mathrm{s}$, the maximum reactivity insertion rate of the control rods is $1.91 \times 10^{-4} \mathrm{dk} / \mathrm{ks}$. For safety analysis, particularly inadvertant control rods withdrawal, a $15 \%$ of safety factor is added. Thus, the maximum reactivity insertion rate of the control rods to be used in the analysis is $2.2 \times 10^{-4}$ $\mathrm{dk} / \mathrm{ks}$.

\section{RESULTS AND DISCUSSTIONS}

Delay time is the interval time between received trip signal through the time when all control rods are fully inserted into the core. The contributors of delay time are the response time of rod driver and dropping time.

$$
T_{\text {delay }}=T_{\text {response }}+T_{\text {rod drop }},
$$

Dropping time of the control rods contributes most dominantly to the delay time, therefore dropping time becomes important part of the OLC 
(Operating Limit and Condition) for reactivity control system of the reactor. System response against delay time should be analized on its adequacy during design basis accident (DBA), particularly reactivity insertion accidents. An accident of inadvertant control rods withdrawal is chosen for analysis on its adequacy, as this sort of accident requires quick response from the control rods to scram the reactor.

\section{Safety Criteria}

At any design basis accident, the fuel and clad temperature should be kept below $200{ }^{\circ} \mathrm{C}$ and 145 ${ }^{\circ} \mathrm{C}$, respectively. As for the minimum safety margin against flow instability (S), it should be kept above 1.48 to prevent the occurence of flow instability at any cooling channel during forced convection cooling. The $\mathrm{S}$ value is defined by:

$$
S=\frac{\eta_{C}}{\eta_{E}}
$$

where $\eta_{E}$ refers to experimental bubble detachment parameter which is $22.1 \mathrm{~cm}^{3} \mathrm{~K} / \mathrm{Ws}$ for RSG GAS system. Meanwhile, $\eta_{C}$ is calculated by PARET/ANL code as:

$$
\eta=\frac{\left[T_{s}(z)-T_{c}(z)\right] V(z)}{q^{\prime \prime}(z)}
$$

where:

$$
\begin{array}{ll}
q^{\prime \prime} & : \text { heat flux, w/ } / \mathrm{cm}^{2} . \\
V & : \text { coolant velocity, } \mathrm{cm} / \mathrm{s} . \\
z & : \text { distance from inlet of cooling }
\end{array}
$$

chanel, $\mathrm{cm}$.

$T_{s}, T_{c} \quad$ : saturated and bulk temperature, respectively, $\mathrm{K}$.

Figure 3 shows the event sequence of inadvertant control rod withdrawal transient with delay time between trip signal and scram of 0.5 second. The reactor power starts to show the increase at the beginning of transient at $t=5.0 \mathrm{~s}$. Trip signal from floating limit value comes at $t=$ $19 \mathrm{~s}$. Trip signal of floating limit value is defined as the percentage of power change per nominal power per unit time. The magnitude of positive floating limit value is $7.0 \% / \mathrm{s}$, which means that when the power increases by $7.0 \%$ of nominal power (30 MW) at one second, the reactor will be triggered to scram.

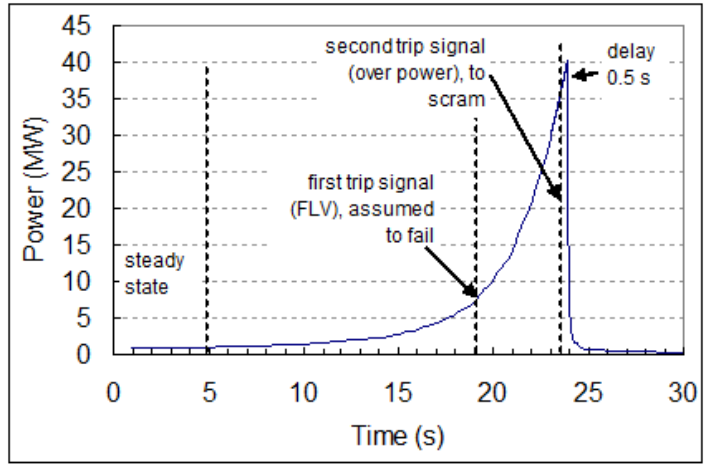

Figure 3. Event sequence of reactivity insertion with delay time of $0.5 \mathrm{~s}$

As the first trip signal from floating limit value is assumed to fail to scram the reactor, the power increase continues until reaching the second trip signal, i.e. over power trip signal. The reactor over power trip signal, which is $114 \%$ of nominal power $(34.2 \mathrm{MW})$, is achieved at $t=$ $23.41 \mathrm{~s}$, as shown in Table 1 . The reactor reaches its peak power $40.26 \mathrm{MW}$, and eventually scrams the reactor after delay time $0.5 \mathrm{~s}$, at $t=23.91 \mathrm{~s}$.

The fuel and clad temperatures at a time of reaching peak power stand at $185.32{ }^{\circ} \mathrm{C}$ and $138.04{ }^{\circ} \mathrm{C}$ respectively, which are well below the limits of $200{ }^{\circ} \mathrm{C}$ and $145{ }^{\circ} \mathrm{C}$, respectively. The flow instability parameter (S) attains its lowest value at 2.25 when reactor power reaches its peak, however this value is well above the limit of 1.48 . Thus, during transient inadvertant control rod wihdrawal, all safety parameters can be maintained at safe condition with delay time between trip signal and scram $0.5 \mathrm{~s}$.

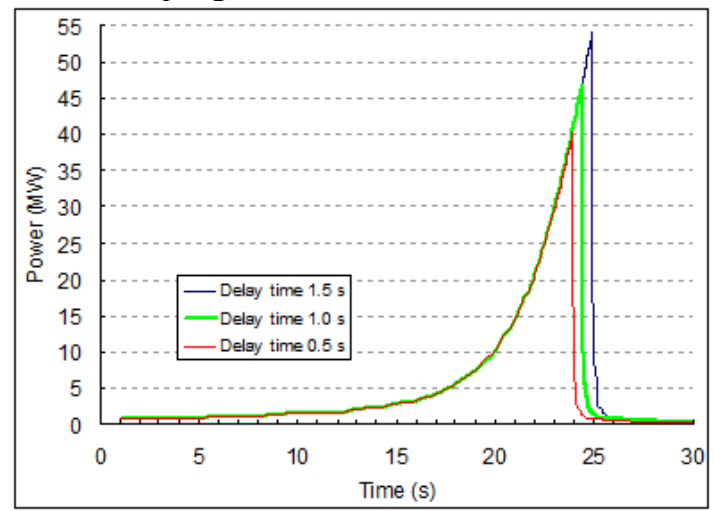

Figure 4. Peak powers at various delay time

Fast increase in power during the interval of delay time will lead to the level of peak power to be reached. Therfore, the longer the daly time, the higher the peak power to be reached. Three analyses have been performed for different delay time, i.e $0.5 \mathrm{~s}, 1.0 \mathrm{~s}$ and $1.5 \mathrm{~s}$. The power transient behaviors during inadvertant control rods 
withdrawal with three scenarios of delay time are shown in Figure 4.

Table 2 presents the peak power level and core safety parameters during inadvertant control rods withdrawal with three sceenarios of delay time. The table implies that for delay time $0.5 \mathrm{~s}$, no single safety parameter exceeds the designated safety limits. As for delay time $1.0 \mathrm{~s}$, the fuel and clad temperatures are kept well below the limits of $200{ }^{\circ} \mathrm{C}$ and $145^{\circ} \mathrm{C}$, respectively. However, the flow instability parameter (S) has exceeded the safety limit 1.48. Lastly for delay time $1.5 \mathrm{~s}$, both fuel temperature and flow instability parameter have exceeded the limits. As a consequence, the delay time between trip signal and scram may not be longer than $0.5 \mathrm{~s}$. In practice, the delay time is identical to the dropping time of the control rods, as dominat contributor to delay time.

Table 1. Transient on control rods withdrawal with delay time of $0.5 \mathrm{~s}$

\begin{tabular}{|c|c|c|}
\hline t (s) & Parameter / phenomenon & value \\
\hline \multicolumn{3}{|c|}{ Steady state } \\
\hline \multirow{3}{*}{$0-5.0$} & Maximum fuel temperature, ${ }^{\circ} \mathrm{C}$ & 50.20 \\
\hline & Maximum coolant temperature at hot channel, ${ }^{\circ} \mathrm{C}$ & 45.89 \\
\hline & Minimum safety margin against flow instability (S) & $\geq 45.0$ \\
\hline \multicolumn{3}{|c|}{ Transient condition } \\
\hline 19.00 & First trip signal (FLV), \%/s & 7.0 \\
\hline 23.41 & Second trip signal (Over power), MW & 34.20 \\
\hline 23.91 & Peak power, MW & 40.26 \\
\hline 23.91 & \multicolumn{2}{|l|}{ Reactor scram } \\
\hline 23.91 & Maximum fuel temperature, ${ }^{\circ} \mathrm{C}$ & 185.32 \\
\hline 23.92 & Maximum clad temperature, ${ }^{\circ} \mathrm{C}$ & 138.04 \\
\hline 23.92 & Minimum safety margin against flow instability (S) & 2.25 \\
\hline 23.94 & Maximum coolant temperature at hot channel, ${ }^{\circ} \mathrm{C}$ & 98.95 \\
\hline \multicolumn{3}{|c|}{ Shutdown condition } \\
\hline \multirow{3}{*}{$\geq 25.00$} & Maximum fuel temperature, ${ }^{\circ} \mathrm{C}$ & 46.10 \\
\hline & Maximum clad temperature, ${ }^{\circ} \mathrm{C}$ & 45.78 \\
\hline & Maximum coolant temperature, ${ }^{\circ} \mathrm{C}$ & 44.89 \\
\hline
\end{tabular}

Table 2 . The cosequence of delay time on safety parameters

\begin{tabular}{|c|c|c|c|c|c|}
\hline \multirow{2}{*}{$\begin{array}{c}\text { Delay time } \\
(\mathbf{s})\end{array}$} & \multirow{2}{*}{$\begin{array}{c}\text { Peak power } \\
(\mathbf{M W})\end{array}$} & \multicolumn{3}{|c|}{ Maximum Temperature } & \multirow{2}{*}{ S Parameter } \\
\cline { 3 - 5 } & & Fuel & Clad & Coolant & \\
\hline 0.5 & 40.26 & 185.32 & 138.04 & 98.95 & 2.25 \\
\hline 1.0 & 46.94 & 193.84 & 138.77 & 108.36 & 1.43 \\
\hline 1.5 & 54.09 & 202.84 & 139.40 & 118.87 & 0.37 \\
\hline
\end{tabular}

\section{CONCLUSIONS}

Calculations have been done to verify the adequacy of delay time in preventing excessive power excursion during inadvertant control rods

withdrawal using PARET/ANL Code. The analysis results confirmed that with delay time less than $0.5 \mathrm{~s}$, control rods can maintain all safety parameters within OLC. However for delay time greater than $1.0 \mathrm{~s}$, some safety limits have been exceeded.

\section{REFERENCES}

[1] BAPETEN, "Ketentuan Keselamatan Desain Reaktor Nondaya (Lampiran II)", Peraturan Kepala BAPETEN No. 1/2011, 2011.

[2] I.D. Abdelrazek, M. Naguib Aly, A.A. Badawi, A.G. Abo Elnour,'Benchmarking RSG GAS reactor thermal hydraulic data using RELAP5 code", Annals of Nuclear Energy, Vol.70, August 2014.

[3] P.H. Liem and T. M. Sembiring,"Design of transition cores of RSG GAS (MPR-30) with higher loading silicide fuel", Nuclear Engineering and Design, Vol.240, p.1433-1442, 2010.

[4] P. H. Liem, A. Bakri, T. M. Sembiring, Prayoto and R. Nabbi,"Fuel management strategy for the new equilibrium silicide core design of RSG GAS (MPR30)", Nuclear Engineering and Design, Vol.180, p.207219, 1998. 
[5] A. Khakim dan P. H. Endiah, "Analisis Kondisi Tunak dan Kecelakaan Reaktivitas pada Mode Pendinginan Sirkulasi Alam Reaktor RSG GAS”, Prosiding Pertemuan dan Presentasi Ilmiah Penelitian Dasar Ilmu Pengetahuan dan Teknologi Nuklir (PDIPTN), Jogjakarta, 13 Juli 2004.

[6] A. Khakim, "Analisis Kecelakaan Pencabutan Cepat Batang Kendali Saat Kenaikan Daya Reaktor RSG GAS”, Buletin Ilmiah Teknologi Keselamatan Nuklir Sigma Epsilon, ISSN 0853-9103, No. 26-27 / AgustusNovember 2002.

[7] A. Khakim, "Aplikasi PARET/ANL untuk Analisis Kecelakaan Pencabutan Cepat Batang Kendali pada Reaktor RSG GAS”, Proceedings Seminar Nasional ke-9 Teknologi dan Keselamatan PLTN serta Fasilitas Nuklir, Jakarta, 20 Agustus 2003.

[8] X-5 Monte Carlo Team, "MCNP- A General Monte Carlo N-Particle Transport Code, Version 5: User's Guide", April 24, 2003.

[9] A. Khakim, "Perhitungan Kritikalitas Gudang Uranium Fasilitas Instalasi Pabrikasi Elemen Bakar Reaktor Riset (IPEBRR)", Proceedings Seminar Nasional ke-18 Teknologi dan Keselamatan PLTN serta Fasilitas Nuklir, UPI-Bandung, 29 September 2012. 